
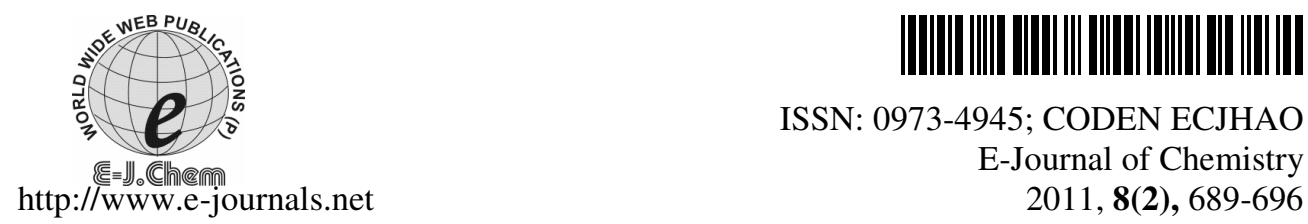

ISSN: 0973-4945; CODEN ECJHAO

E-Journal of Chemistry $2011,8(2), 689-696$

\title{
Bulk and Activated Carbon-Supported Tungstophosphoric Acid as Recyclable and Green Catalyst for One-Pot Synthesis of $\beta$-Acetamido Ketones and Esters
}

\author{
FATEMEH F. BAMOHARRAM ${ }^{*}$, ALI AHMADPOUR ${ }^{\S}$, \\ MAJID M. HERAVI ${ }^{\#}$ and MOHAMMAD J. SANE CHARKHI \\ *Department of Chemistry, School of Sciences \\ Islamic Azad University - Mashhad Branch, Mashhad, Iran \\ ${ }^{\S}$ Department of Chemical Engineering \\ Ferdowsi University of Mashhad, Mashhad, Iran \\ \#Department of Chemistry \\ School of Sciences, Azzahra University, Tehran, Iran \\ Member of Young Researchers Club \\ Islamic Azad University - Mashhad Branch, Mashhad, Iran \\ fbamoharram@mshdiau.ac.ir
}

Received 10 August 2010; Accepted 8 November 2010

\begin{abstract}
A rapid and efficient one-pot method for the synthesis of $\beta$-acetamido ketones/esters has been developed in the presence of bulk tungstophosphoric acid and its supported forms on activated carbon as recyclable and eco-friendly catalysts under refluxing conditions. Supported tungstophosphoric acid catalysts containing the same amount of heteropoly acid yielded much higher conversion than bulk form.
\end{abstract}

keywords: Catalyst, Heteropoly acid, Tungstophosphoric acid, Multi-component reaction, $\beta$-acetamido ketones/esters.

\section{Introduction}

$\beta$-acetamido ketones are useful intermediates in different organic syntheses due to their polyfunctional nature and presence in several bioactive compounds ${ }^{1,2}$. They can be converted into 3-amino alcohols, which may be applied for the synthesis of various important antibiotics ${ }^{3}$. The most interesting reaction for the synthesis of these compounds is by multicomponent coupling involving aromatic aldehyde, ketone, acetyl chloride and 
acetonitrile as first reported by Iqbal and co-workers ${ }^{4}$. The best known route for the synthesis $\beta$-acetamido carbonyl compounds, is the Dakin-West reaction ${ }^{5}$, which involves the condensation of an $\alpha$-amino acid with acetic anhydride in the presence of a base via an azalactone intermediate ${ }^{6}$.

Multicomponent coupling reactions ${ }^{7}$ (MCRs) are attractive for parallel synthesis as large arrays of compounds with diverse substitution patterns can be prepared in one-step, often in high yields, under mild conditions. MCRs are powerful tools in modern drug discovery and allow fast, automated and high throughput synthesis of diverse structural scaffolds required in the search of novel therapeutic molecules.

Recently, a number of reports have been described on the synthesis of $\beta$-acetamido ketones through multicomponent condensation of aryl aldehydes, enolizable ketones, acetyl chloride and acetonitrile catalyzed by $\mathrm{CoCl}_{2}{ }^{8}$, Montmorillonite K-10 clay ${ }^{9}, \mathrm{SiO}_{2}-\mathrm{H}_{2} \mathrm{SO}_{4}{ }^{10}$, silica sulfuric acid ${ }^{10}, \mathrm{ZrOCl}_{2} \cdot 8 \mathrm{H}_{2} \mathrm{O}^{11}$ and $\mathrm{Sc}(\mathrm{OTf})_{3}{ }^{12}$.

Although some of these methodologies are efficient and provide the practical means for the synthesis of $\beta$-acetamido ketones, some of the reported methods suffer from drawbacks such as longer reaction times, tedious work up, higher temperatures, expensive catalysts, lower yields and requiring an inert atmosphere.

In recent years considerable emphasis has been focused on improvement in environmental impact of industrial processes. Solid acids can play a significant role in the development of cleaner technologies ${ }^{13}$.

Heteropoly acids are a group of inorganic polyacids, with a great applications in many areas, including technological, catalysis, chemical, medical and material science ${ }^{14}$. They are nonvolatile, inexpensive, low in toxicity, highly stable towards humidity, air stable and noncorrosive common inorganic acids and could be readily recycled and reused through a simple filtration and washing. These compounds can be used either directly as a bulk material or in supported form. The supported form is preferable because of its higher surface area compared with the bulk material $\left(5-8 \mathrm{~m}^{2} \mathrm{~g}^{-1}\right)$ and better accessibility of reactants to the active sites. Acidic or neutral solids, which interact weakly with them such as silica, active carbon and acidic ion-exchange resins, have been reported to be suitable supports ${ }^{15}$. In addition, heteropoly acids are highly soluble in polar solvents and hence can leach from the catalyst surface to the reaction medium and catalyze the reaction homogeneously. Thus the preparation of heteropoly acid in supported form, which is active and stable in the presence of polar reactants, is essential to fully realize the potential of these materials as catalysts.

Using activated carbon as a support is widely known ${ }^{16}$, denoting properties such as their high surface area and pore volume ${ }^{18}$, chemical inertness, good mechanical and $\mathrm{pH}$ stability ${ }^{16-18}$. Thus, several studies have been carried out using activated carbon as supports of heteropoly acids $^{16,19}$.

Some of them have been focused in the study of the catalytic application on some liquid-phase reactions, while the others have tried to analyze the variation of the acidity strength of bulk heteropoly acid when supported on activated carbon. Most of these methods have been focused on the surface area of heteropoly acid and attention to the support has been ignored. Further, the performance of supported heteropoly acids on activated carbon in MCRs in one-pot syntheses has been largely overlooked. Based on our previous studies on the use of heteropoly acid catalysts for carrying organic reactions ${ }^{20-26}$, herein, we wish to report an efficient and convenient procedure for the one-pot synthesis of $\beta$-acetamido ketones and esters using tungstophosphoric acid as bulk and supported on activated carbon. 


\section{Experimental}

Tungstophosphoric acid was synthesized according to the literature ${ }^{27}$. All of the chemicals were obtained from commercial sources. All yields were calculated from purified products. IR spectra were obtained with a Brucker 500 scientific spectrometer. ${ }^{1} \mathrm{H}$ NMR spectra were recorded on a FT NMR $300 \mathrm{HZ}$ spectrometer. Melting points were obtained on a Electro thermal type 9100 apparatus.

Three types of activated carbon have been selected as supports for impregnation of heteropolyacids. Two samples are chemically activated and for their preparation, local anthracite is used. Mass ratio of chemical/anthracite $\mathrm{R}=2$, activation temperatures of $\mathrm{T}=730{ }^{\circ} \mathrm{C}$ and residence time of $2 \mathrm{~h}$ at final temperature have been studied. When activating agent was $\mathrm{KOH}$, activated carbon abbreviated as $\mathrm{AK}$ and when it was $\mathrm{NaOH}$, activated carbon abbreviated as AN. They prepared with anthracite ratio of $2.5 / 1$ and pyrolyzed at $730^{\circ} \mathrm{C}$ for $2 \mathrm{~h}$. The activated carbon with abbreviation of WS was prepared from walnut shell.

The porous texture of the supported $\mathrm{AC}$ and the precursor were characterized by a physical adsorption of gas of $\mathrm{N}_{2}$ at $77 \mathrm{~K}$ in a volumetric equipments (Autosorb-1C). Before the adsorption tests, samples were outgassed at $473 \mathrm{~K}$ under vacuum during over $10 \mathrm{~h}$. Apparent surface area was determined by applying the Brunauer- Emmett-Teller (BET) equation. The Dubinin-Radushkevich (DR) equation has been used to calculate the micropore volume, while the t-method of De Boer has been used to calculate the mesopore volume.

The catalysts were prepared by suspending a known amount of dried activated carbon powder in an aqueous solution of tungstophosphoric acid. Activated carbon was prepared by mixing of carbon powder with $\mathrm{NaOH}$ solution followed by the dropwise addition of aqueous $\mathrm{HCl}$ to a final acidic $\mathrm{pH}$. The mixture was stirred with $\mathrm{HNO}_{3}$ and then the precipitate was filtered, washed, dried and stirred with $\mathrm{HNO}_{3}$ at $100{ }^{\circ} \mathrm{C}$ for $48 \mathrm{~h}$. The obtained powder filtered and dried for another $8 \mathrm{~h}$. They are abbreviated as: PAK, PAN and PWS (Abbreviations for supported $\mathrm{H}_{3}\left[\mathrm{PW}_{12} \mathrm{O}_{40}\right]$ on $\mathrm{AK}, \mathrm{AN}$ and WS, respectively) .

\section{General procedure}

A mixture of ketone or methylacetoacetate $(1 \mathrm{mmol})$, aromatic aldehyde $(1.1 \mathrm{mmol})$ and acetyl chloride $(4 \mathrm{mmol})$ in acetonitrile $(4 \mathrm{~mL})$ was made with a catalytic amount of $\mathrm{H}_{3}\left[\mathrm{PW}_{12} \mathrm{O}_{40}\right]$ as bulk and supported on activated carbon including : PAK, PAN and PWS at $80{ }^{\circ} \mathrm{C}$. The progress of reaction was monitored by TLC and GC. After completion of the reaction, the mixture was poured into cold water, which resulted in precipitation of the desired $\beta$-acetamido ketones/esters. The precipitated solid was filtered and washed with diethylether. The pure product was obtained by recrystallization. The catalyst could be recycled after evaporation of solvent from the residue. The residue then washed with diethyl ether, dried at $130{ }^{\circ} \mathrm{C}$ for $1 \mathrm{~h}$ and re-used in another reaction. The recycled catalyst was used for three reactions without observation of appreciable loss in its catalytic activities.

\section{Results and Discussion}

The pure activated carbons dried at $120{ }^{\circ} \mathrm{C}$ were showed different surface areas, pore volumes, average pore diameters and densities. The structural characteristics of them are shown in Table 1 and $\mathrm{N}_{2}$ isotherms are shown in Figure 1. The pore volume distribution of samples is plotted in Figure 2 using HK methods ${ }^{28}$. The structural characteristics of supported samples are shown in Table 2. As we can see, after impregnation of activated carbons with tungstophosphoric acid, surface area, pore volume and average pore diameters were decreased. This was due to the strong interaction of tungstophosphoric acid with the support, which reduces the surface area. $\mathrm{N}_{2}$ isotherms and pore volume distribution of impregnated samples are shown in Figures 3 and 4. 
Table 1. The structural characteristics of activated carbon samples

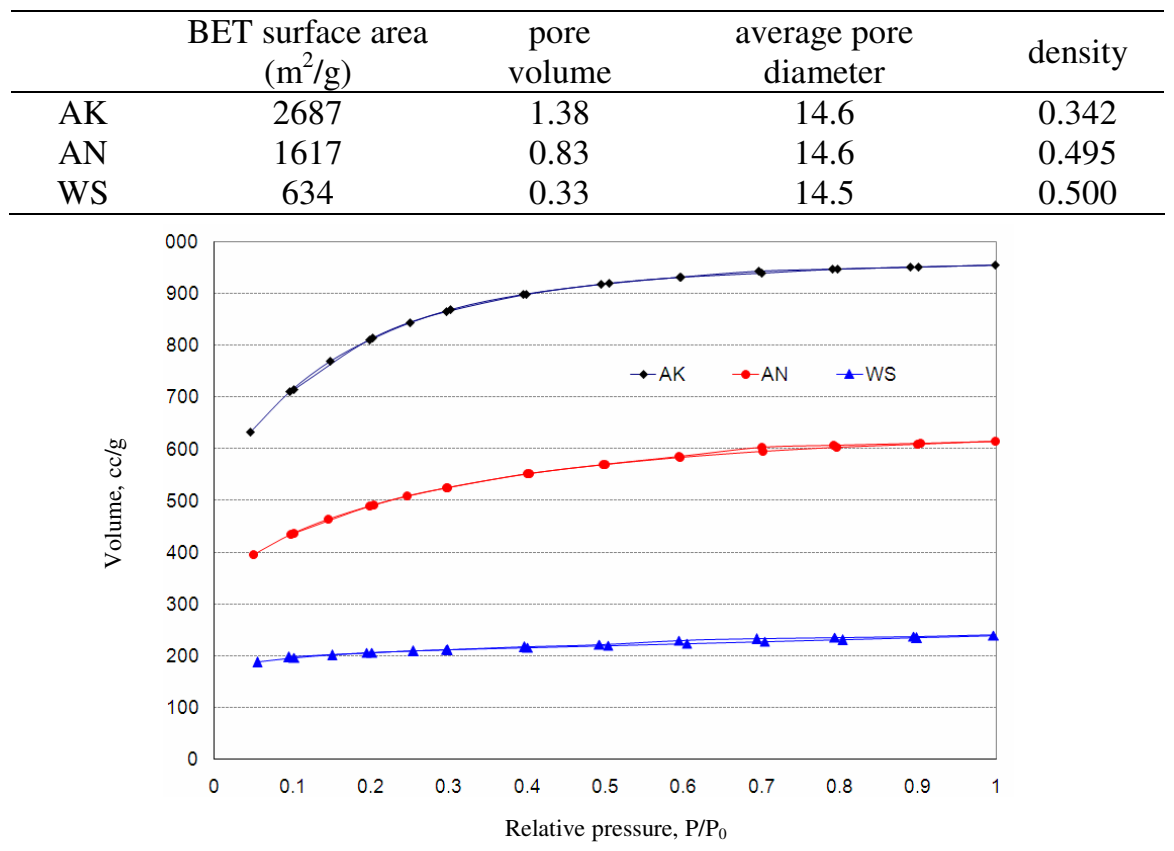

Figure 1. Nitrogen isotherms of activated carbons

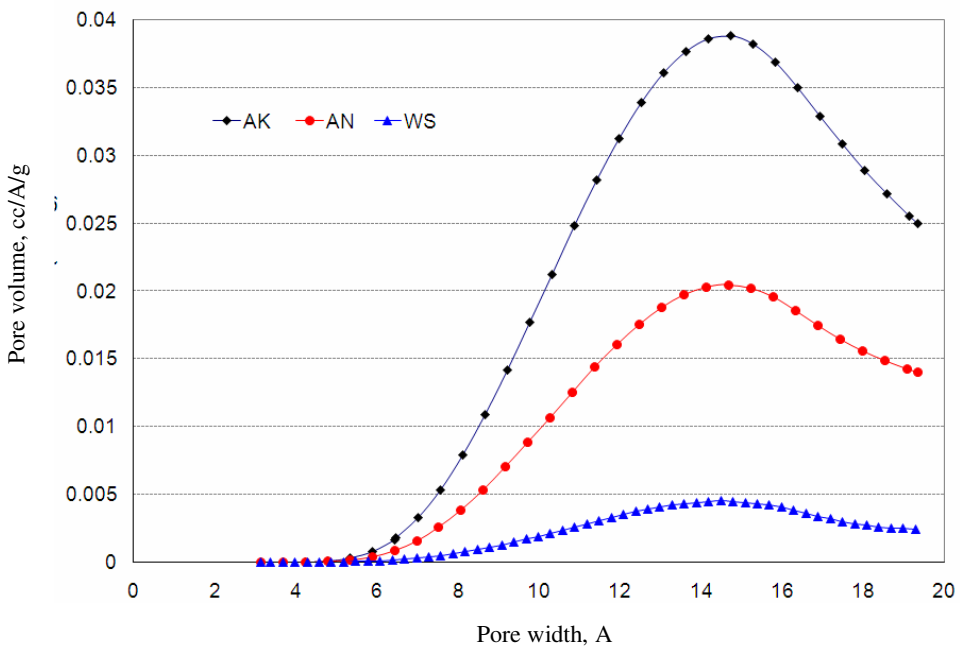

Figure 2. Pore volume distribution of activated carbon samples using HK methods

Table 2. The structural characteristics of supported samples

\begin{tabular}{cccc}
\hline & $\begin{array}{c}\text { BET surface area, } \\
\mathrm{m}^{2} / \mathrm{g}\end{array}$ & pore volume & $\begin{array}{c}\text { average pore } \\
\text { diameter }\end{array}$ \\
\hline PAK & 496 & 0.26 & 14.1 \\
PAN & 400 & 0.21 & 14.5 \\
PWS & 396 & 0.26 & 14.4 \\
\hline
\end{tabular}




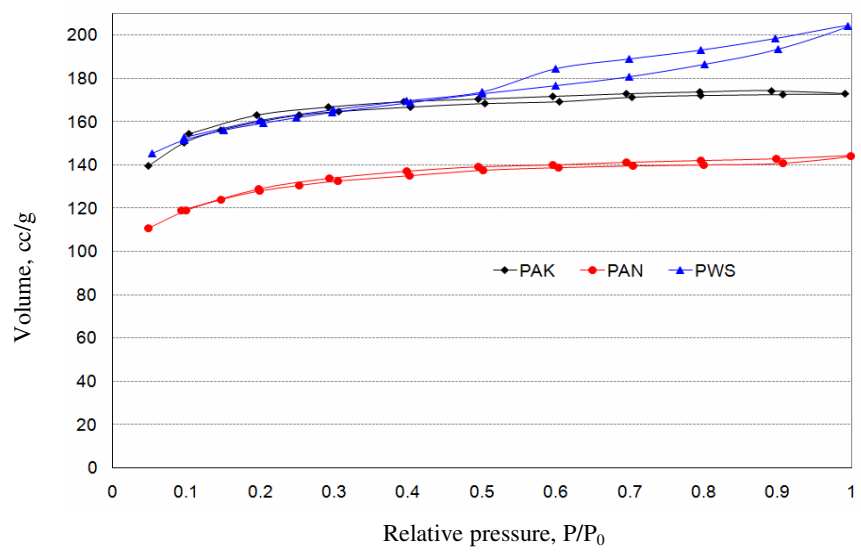

Figure 3. $\mathrm{N}_{2}$ isotherms of the impregnated samples

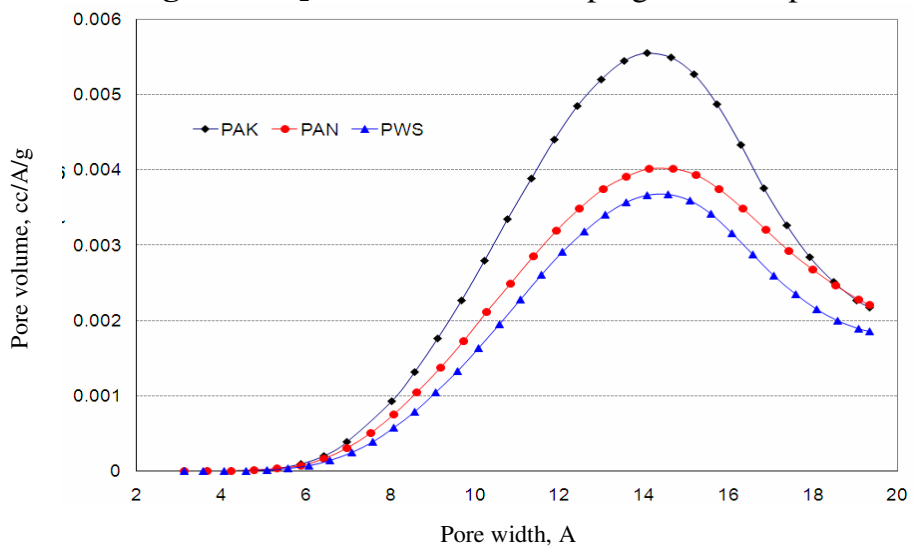

Figure 4. Pore volume distribution of impregnated samples using HK methods

The synthesis of $\beta$-acetamido ketones and esters in the presence of a catalytic amount of the synthesized supported catalysts investigated under reflux conditions in acetonitrile as solvent (Scheme 1). The suggested mechanism is shown in Scheme 2.

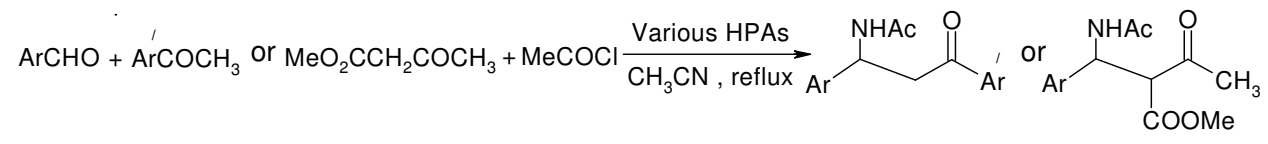

\section{Scheme 1}

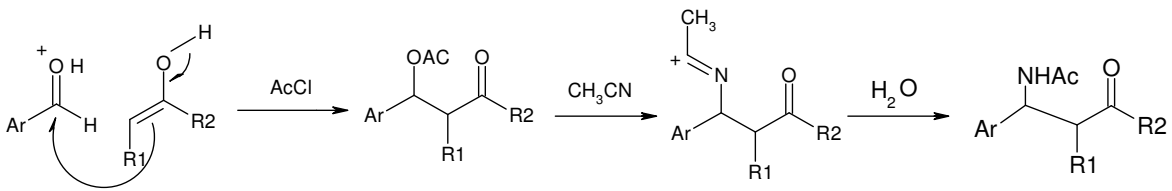

\section{Scheme 2}

To study the effect of the catalyst on this reaction, 4-chlorobenzaldehyde was selected as optimized and model reactant and the yields of the products were obtained using different catalysts. The results are shown in Table 3. As we can see the order of efficiency of Keggin heteropolyacids supported on actived carbon catalysts is as : PAK > PAN > PWS > $\mathrm{H}_{3} \mathrm{PW}_{12} \mathrm{O}_{40}$. Also time of reaction is lower in the presence of PAK. It is difficult to clarify the 
different activity between these anions clearly. Obviously there is a complex relationship between the activity and structure of polyanions and supports. It is suggested that the presence of both Bronsted acidity and surface area in the mentioned heteropolyacids, are responsible for catalytic activity of them. The greater surface area may provide many sites for catalytic reaction and can reduce reaction time.Thus, PAK heteropolyacid, were selected as the catalysts of choice for the synthesis of the other $\beta$-acetamido ketones/esters. Data are shown in Table 4.

Table 3. Effect of supported heteropolyacids, on the yields of $\beta$-acetamido- $\beta$ (4chlorophenyl) propiophenone, as optimized and model product under reflux condition

\begin{tabular}{cccc}
\hline Entry & Heteropolyacid & Time, min & Yield, $\%^{\mathrm{a}}$ \\
\hline 1 & PAK & 45 & 98 \\
2 & PAN & 50 & 81 \\
3 & PWS & 65 & 76 \\
4 & $\mathrm{H}_{3}\left[\mathrm{PW}_{12} \mathrm{O}_{40}\right]$ & 80 & 63 \\
\hline \multicolumn{4}{c}{ Yield refers to isolated products }
\end{tabular}

Table 4. synthesis of $\beta$-acetamido ketones and esters using catalytic amount of PAK under reflux condition

\begin{tabular}{|c|c|c|c|c|c|c|}
\hline \multirow{2}{*}{ Entry } & \multirow{2}{*}{ Aldehyde } & \multirow{2}{*}{ Carbonylcompound } & \multirow{2}{*}{$\begin{array}{c}\text { Time } \\
\text { min }\end{array}$} & \multirow{2}{*}{$\begin{array}{c}\text { Yield, } \\
\%\end{array}$} & \multicolumn{2}{|c|}{$\mathrm{m} \cdot \mathrm{p}$} \\
\hline & & & & & Found & Reported $^{\text {Ref }}$ \\
\hline 1 & $4-\mathrm{ClC}_{6} \mathrm{H}_{4} \mathrm{CHO}$ & $\mathrm{C}_{6} \mathrm{H}_{5} \mathrm{COCH}_{3}$ & 45 & 92 & 148 & $146-148^{29 a}$ \\
\hline 2 & $\mathrm{C}_{6} \mathrm{H}_{5} \mathrm{CHO}$ & $\mathrm{C}_{6} \mathrm{H}_{5} \mathrm{COCH}_{3}$ & 45 & 81 & 106 & $102-104^{30}$ \\
\hline 3 & $3-\mathrm{NO}_{2} \mathrm{C}_{6} \mathrm{H}_{4} \mathrm{CHO}$ & $\mathrm{C}_{6} \mathrm{H}_{5} \mathrm{COCH}_{3}$ & 55 & 84 & $116-118$ & $112-115^{30}$ \\
\hline 4 & 4- $\mathrm{NO}_{2} \mathrm{C}_{6} \mathrm{H}_{4} \mathrm{CHO}$ & $\mathrm{C}_{6} \mathrm{H}_{5} \mathrm{COCH}_{3}$ & 50 & 86 & 153 & $148-149^{30}$ \\
\hline 5 & $4-\mathrm{CH}_{3} \mathrm{OC}_{6} \mathrm{H}_{4} \mathrm{CHO}$ & $\mathrm{C}_{6} \mathrm{H}_{5} \mathrm{COCH}_{3}$ & 45 & 83 & $111-112$ & $115-117^{31}$ \\
\hline 6 & $4-\mathrm{CH}_{3} \mathrm{C}_{6} \mathrm{H}_{4} \mathrm{CHO}$ & $\mathrm{C}_{6} \mathrm{H}_{5} \mathrm{COCH}_{3}$ & 55 & 80 & 110 & $112-114^{29 b}$ \\
\hline 7 & $\mathrm{C}_{6} \mathrm{H}_{5} \mathrm{CHO}$ & $\mathrm{CH}_{3} \mathrm{O}_{2} \mathrm{CCH}_{2} \mathrm{COCH}_{3}$ & 50 & 68 & 133 & $129-131^{29 c}$ \\
\hline 8 & $4-\mathrm{ClC}_{6} \mathrm{H}_{4} \mathrm{CHO}$ & $\mathrm{CH}_{3} \mathrm{O}_{2} \mathrm{CCH}_{2} \mathrm{COCH}_{3}$ & 45 & 72 & $137-138$ & $130-132^{29 c}$ \\
\hline
\end{tabular}

Yield mentioned to the isolated products

To determine the optimum amount of catalyst, $\beta$-acetamido- $\beta$ (4-chlorophenyl) propiophenone (Table 4, Entry 1), was selected as optimized and model product with the best yield, in the presence of PAK heteropolyacid (1\%, $2 \%$ and $3 \mathrm{~mol} \%)$. The results are shown in Figure 5 . It is clear that the yields depend on the amount of catalyst and the optimum amount is $2 \mathrm{~mol} \%$ for all derivatives. Increase in this amount has not any effect on the obtained yields.

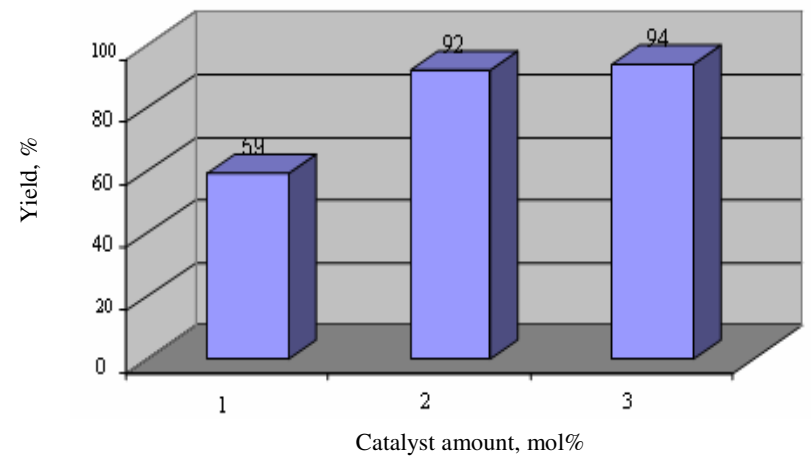

Figure 5. Different amount of PAK heteropolyacid for synthesis of $\beta$-acetamido- $\beta$ (4chlorophenyl) propiophenone 


\section{Spectroscopic data for the compounds from Table 4}

Entry 1: $v_{\max }(\mathrm{KBr}): 3291,2329,1687,1647,1547,1445,1349,1229,1009,754 \mathrm{~cm}^{-1}$; $\delta_{\mathrm{H}}\left(\mathrm{CDCl}_{3}\right) 2.01(3 \mathrm{H}, \mathrm{s}, \mathrm{COMe}), 3.41(1 \mathrm{H}, \mathrm{dd}, \mathrm{J} 6.0,16.8 \mathrm{~Hz}, \mathrm{CH} 2), 3.73(1 \mathrm{H}, \mathrm{dd}, \mathrm{J} 5.2$, $17.2 \mathrm{~Hz}, \mathrm{CH} 2), 5.50-5.55(1 \mathrm{H}, \mathrm{m}, \mathrm{CH}), 6.74(1 \mathrm{H}, \mathrm{d}, \mathrm{J} 7.2 \mathrm{~Hz}, \mathrm{NH}), 7.25(4 \mathrm{H}, \mathrm{d}, \mathrm{J} 4.4 \mathrm{~Hz}$ Ph), 7.44 (2H, t, J $8.0 \mathrm{~Hz}, \mathrm{Ph}), 7.56(1 \mathrm{H}, \mathrm{t}, \mathrm{J} 7.6 \mathrm{~Hz}, \mathrm{Ph}), 7.87$ (2H, d, J $8.4 \mathrm{~Hz}, \mathrm{Ph})$;

Entry 2: $v_{\max }(\mathrm{KBr}): 3278,3099,2925,1682,1646,1556,1447,1372,1195,990,750 \mathrm{~cm}^{-1}$; $\delta_{\mathrm{H}}\left(\mathrm{CDCl}_{3}\right) 2.01(3 \mathrm{H}, \mathrm{s}, \mathrm{COMe}), 3.43(1 \mathrm{H}, \mathrm{dd}, \mathrm{J} 6.0,16.8 \mathrm{~Hz}, \mathrm{CH} 2), 3.75(1 \mathrm{H}, \mathrm{dd}, \mathrm{J} 5.2$, $16.8 \mathrm{~Hz}, \mathrm{CH} 2), 5.53-5.57(1 \mathrm{H}, \mathrm{m}, \mathrm{CH}), 6.68(1 \mathrm{H}, \mathrm{d}, \mathrm{J} 7.6 \mathrm{~Hz}, \mathrm{NH}), 7.19-7.30(5 \mathrm{H}, \mathrm{m}, \mathrm{Ph})$, $7.43(2 \mathrm{H}, \mathrm{t}, \mathrm{J} 8.0 \mathrm{~Hz}, \mathrm{Ph}) 7.55(1 \mathrm{H}, \mathrm{t}, \mathrm{J} 7.6 \mathrm{~Hz}, \mathrm{Ph}), 7.88(2 \mathrm{H}, \mathrm{d}, \mathrm{J} 8.0 \mathrm{~Hz}, \mathrm{Ph})$;

Entry 3: $v_{\max }(\mathrm{KBr}): 3306,1693,1644,1545,1522,1347,983,684 \mathrm{~cm}^{-1} ; \delta_{\mathrm{H}}\left(\mathrm{CDCl}_{3}\right)$ $2.08(3 \mathrm{H}, \mathrm{s}, \mathrm{COMe}), 3.51(1 \mathrm{H}, \mathrm{dd}, \mathrm{J} 5.6,17.6 \mathrm{~Hz}, \mathrm{CH} 2), 3.79(1 \mathrm{H}, \mathrm{dd}, \mathrm{J} 5.2,17.6 \mathrm{~Hz}, \mathrm{CH} 2)$, 5.62-5.67 (1H, m, CH), $6.91(1 \mathrm{H}, \mathrm{d}, \mathrm{J} 7.6 \mathrm{~Hz}, \mathrm{NH}), 7.42-7.49(3 \mathrm{H}, \mathrm{m}, \mathrm{Ph}), 7.57(1 \mathrm{H}, \mathrm{t}, \mathrm{J} 7.6$ $\mathrm{Hz}, \mathrm{Ph}), 7.68(1 \mathrm{H}, \mathrm{d}, \mathrm{J} 7.6 \mathrm{~Hz}, \mathrm{Ph}), 7.87$ (2H, d, J 7.6 Hz, Ph), 8.06 (1H, d, J $6.8 \mathrm{~Hz}, \mathrm{Ph})$, $8.19(1 \mathrm{H}, \mathrm{s}, \mathrm{Ph})$;

Entry 4: $v_{\max }(\mathrm{KBr}): 3306,1696,1646,1595,1537,1350,988,755 \mathrm{~cm}^{-1} ; \delta_{\mathrm{H}}\left(\mathrm{CDCl}_{3}\right)$ $2.10(3 \mathrm{H}, \mathrm{s}, \mathrm{COMe}), 3.51(1 \mathrm{H}, \mathrm{dd}, \mathrm{J} 5.6,17.6 \mathrm{~Hz}, \mathrm{CH} 2), 3.81(1 \mathrm{H}, \mathrm{dd}, \mathrm{J} 5.2,17.6 \mathrm{~Hz}, \mathrm{CH} 2)$, 5.65-5.67 (1H, m, CH), $6.96(1 \mathrm{H}, \mathrm{d}, \mathrm{J} 8.0 \mathrm{~Hz}, \mathrm{NH}), 7.47(2 \mathrm{H}, \mathrm{t}, \mathrm{J} 8.0 \mathrm{~Hz}, \mathrm{Ph}), 7.51(2 \mathrm{H}, \mathrm{d}, \mathrm{J}$ $8.8 \mathrm{~Hz}, 2 \mathrm{H}, \mathrm{Ph}), 7.60(1 \mathrm{H}, \mathrm{t}, \mathrm{J} 7.2 \mathrm{~Hz}, \mathrm{Ph}), 7.89$ (2H, d, J 7.2 Hz, Ph), 8.17 (2H, d, J $8.8 \mathrm{~Hz}$, $\mathrm{Ph})$;

Entry 5: $v_{\max }(\mathrm{KBr}): 3301,2928,1688,1648,1545,1372,1238,1033,754 \mathrm{~cm}^{-1} ; \delta_{\mathrm{H}}$ $\left(\mathrm{CDCl}_{3}\right) 2.0(3 \mathrm{H}, \mathrm{s}, \mathrm{COMe}), 3.39(1 \mathrm{H}, \mathrm{dd}, \mathrm{J} 6.4,16.8 \mathrm{~Hz}, \mathrm{CH} 2), 3.72(1 \mathrm{H}, \mathrm{dd}, \mathrm{J} 5.2,17.2$ $\mathrm{Hz}, \mathrm{CH} 2), 3.74(3 \mathrm{H}, \mathrm{s} \mathrm{OMe}), 5.46-5.51(1 \mathrm{H}, \mathrm{m}, \mathrm{CH}), 6.57(1 \mathrm{H}, \mathrm{d}, \mathrm{J} 8.0 \mathrm{~Hz}, \mathrm{NH}), 6.81(2 \mathrm{H}$, d, J $8.4 \mathrm{~Hz}, \mathrm{Ph}), 7.23(2 \mathrm{H}, \mathrm{d}, \mathrm{J} 8.0 \mathrm{~Hz}, \mathrm{Ph}), 7.42(2 \mathrm{H}, \mathrm{t}, \mathrm{J} 7.6 \mathrm{~Hz}, \mathrm{Ph}), 7.54(1 \mathrm{H}, \mathrm{t}, \mathrm{J} 7.2 \mathrm{~Hz}$, $\mathrm{Ph}), 7.89$ (2H, d, J 7.2 Hz, Ph);

Entry 6: $v_{\max }(\mathrm{KBr}): 3285,2923,1684,1651,1550,1374,1292,1006,757 \mathrm{~cm}^{-1} ; \delta_{\mathrm{H}}$ $\left(\mathrm{CDCl}_{3}\right) 2.0(3 \mathrm{H}, \mathrm{s}, \mathrm{COMe}), 2.28\left(3 \mathrm{H}, \mathrm{s}, \mathrm{CH}_{3}\right), 3.37(1 \mathrm{H}, \mathrm{dd}, \mathrm{J} 6.4,16.8 \mathrm{~Hz}, \mathrm{CH} 2), 3.71(1 \mathrm{H}$, dd, J 5.2, 17.2 Hz, CH2), 3.75 (3H, s OMe), 5.46-5.51 (1H, m, CH), $6.57(1 \mathrm{H}, \mathrm{d}, \mathrm{J} 8.0 \mathrm{~Hz}$, $\mathrm{NH}), 6.81(2 \mathrm{H}, \mathrm{d}, \mathrm{J} 8.4 \mathrm{~Hz}, \mathrm{Ph}), 7.24(2 \mathrm{H}, \mathrm{d}, \mathrm{J} 8.0 \mathrm{~Hz}, \mathrm{Ph}), 7.44(2 \mathrm{H}, \mathrm{t}, \mathrm{J} 7.6 \mathrm{~Hz}, \mathrm{Ph}), 7.53$ $(1 \mathrm{H}, \mathrm{t}, \mathrm{J} 7.2 \mathrm{~Hz}, \mathrm{Ph}), 7.88(2 \mathrm{H}, \mathrm{d}, \mathrm{J} 7.2 \mathrm{~Hz}, \mathrm{Ph})$;

Entry 7: $v_{\max }(\mathrm{KBr}): 3329,3049,2961,1747,1717,1643,1528,1451,1371,1037,754$ $\mathrm{cm}^{-1} ; \delta_{\mathrm{H}}\left(\mathrm{CDCl}_{3}\right) 1.99(3 \mathrm{H}, \mathrm{s}, \mathrm{COMe}), 2.10(3 \mathrm{H}, \mathrm{s}, \mathrm{COMe}), 3.69(3 \mathrm{H}, \mathrm{s}, \mathrm{OMe}), 4.07(1 \mathrm{H}, \mathrm{d}, \mathrm{J}$ $5.6 \mathrm{~Hz}, \mathrm{CH}), 5.73(1 \mathrm{H}, \mathrm{dd}, \mathrm{J} 5.6,9.2 \mathrm{~Hz}, \mathrm{CH}), 6.91(1 \mathrm{H}, \mathrm{d}, \mathrm{J} 8.4 \mathrm{~Hz}, \mathrm{NH}), 7.23-7.31(5 \mathrm{H}, \mathrm{m}, \mathrm{Ph})$;

Entry 8: $v_{\max }(\mathrm{KBr}): 3324,1744,1714,1646,1541,1486,1371,1091,724 \mathrm{~cm}^{-1} ; \delta_{\mathrm{H}}$ $\left(\mathrm{CDCl}_{3}\right) 1.99(3 \mathrm{H}, \mathrm{s}, \mathrm{COMe}), 2.13(3 \mathrm{H}, \mathrm{s}, \mathrm{COMe}), 3.70(3 \mathrm{H}, \mathrm{s}, \mathrm{OMe}), 4.04(1 \mathrm{H}, \mathrm{d}, \mathrm{J} 5.6 \mathrm{~Hz}$, $\mathrm{CH}), 5.68(1 \mathrm{H}, \mathrm{dd}, \mathrm{J} 5.6,9.2 \mathrm{~Hz}, \mathrm{CH}), 6.94(1 \mathrm{H}, \mathrm{d}, \mathrm{J} 8.4 \mathrm{~Hz}, \mathrm{NH}), 7.20(2 \mathrm{H}, \mathrm{d}, \mathrm{J} 8.8 \mathrm{~Hz}, \mathrm{Ph})$, $7.25(2 \mathrm{H}, \mathrm{d}, \mathrm{J} 8.0 \mathrm{~Hz}, \mathrm{Ph})$;

\section{Conclusion}

In conclusion, we have reported a new catalytic method for the synthesis of $\beta$-acetamido ketones/esters using PAK, PAN and PWS as efficient, reusable and eco-friendly heterogeneous catalysts. The advantages of this method are reusability of catalysts, easy work-up procedure and high yields. Simple experimental procedure as well as high yield and selectivity, makes this method useful addition to the methodologies that require green super acid solid catalyst.

\section{References}

1. Casimir J R, Turetta C, Ettouati L and Paris J, Tetrahedron lett., 1995, 36, 4797-4800. 
2. Godfrey A G, Brooks D A, Hay L A, Peters M, McCarthy J R and Mitchell D, J Org Chem., 2003, 68, 2623.

3. Kobinata K, Uramoto M, Nishii M, Kusakabe H, Nakamura G and Isono K, Agric Biol Chem., 1980, 44, 1709.

4. $\quad$ Rao I N, Prabhakaran E N, Das S K and Iqbal J, J Org Chem., 2003, 68, 4079.

5. Dakin H D and West R, J Biol Chem., 1928, 78, 745.

6. Buchanan G L, Chem Soc Rev., 1988, 17, 91.

7. (a) Domling A and Ugi I, Chem Int Ed., 2000, 39, 3168; (b) Thomson L A and Ellman J A, Chem Rev., 1996, 96, 555-600.

8. (a) Reddy M M, Bhatia B and Iqbal J, Tetrahedron Lett., 1995, 36, 877; (b) Mukhopadhyay M, Bhatia B and Iqbal J, Tetrahedron Lett., 1997, 38, 1083-1086.

9. Bahulayan D, Das S K and Iqbal J, J Org Chem., 2003, 68, 5735.

10. Khodaei M M, Khosropour A R and Fattahpour P, Tetrahedron Lett., 2005, 46, 2105-2108.

11. Ghosh R, Maiti S, Chakraborty A, Chakraborty S and Mukherjee A K, Tetrahedron., 2006, 62, 4059.

12. Pandy G, Singh R S, Garg A and Singh V K, Tetrahedron Lett., 2005, 46, 2137.

13. Smith K, Solids Supports and Catalysts in Organic Synthesis, Ellis Horwood, Chichester, 1992.

14. Kozhevnikov I V, Chem Rev., 1998, 98, 171-198.

15. Wu Y, Ye X, Yang X, Wang X, Chu W and Hu Y, Ind Eng Chem Res., 1996, 35, 2546.

16. (a) Jüntgen H, Fuel., 1986, 65, 1436; (b) Auer E, Freund A, Pietsch J and Tacke T, Appl Catal.,1998, 173, 259.

17. Villar-Rodil S, Suarez-Garcia F, Paredes J I, Martinez-Alonso A and Tascón J M D, Chem Mater., 2005, 17, 5893.

18. Sakintuna B and Yürüm Y, Ind Eng Chem Res., 2005, 44, 2893.

19. Izumi Y and Urabe k, Chem Lett., 1981, 663.

20. Bamoharram F F, Heravi M M, Roshani M, Jahangir M and Gharib A, J Mol Catal A: Chem., 2007, 271, 126.

21. Bamoharram F F, Heravi M M, Roshani M and Toosi M, Green Chem Lett Rev., 2009, 2, 35.

22. Bamoharram F F, Heravi M M, Roshani M and Akbarpour M, J Mol Catal A: Chem., 2006, 255, 193.

23. Bamoharram F F, Heravi M M, Roshani M and Tavakoli N, J Mol Catal A: Chem., 2006, 252, 219.

24. Bamoharram F F, Heravi M M, Heravi H M and Meraji M, Int J Green Nanotech: Phy Chem., 2009, 1, 26-31.

25. Bamoharram F F, Heravi M M, Alizadeh M H, Razavi H and Moghayadi M, J Braz Chem Soc., 2006, 17, 505.

26. Bamoharram F F, Heravi M M, Roshani M, Jahangir M and Gharib A, J Appl Catal., 2006, 302, 42-47.

27. Kozhevnikov I V, Catalysts for fine Chemical Synthesis Catalysis by Polyoxometalates, Wiley, England, 2002, 2.

28. (a) Jaroniec M, Choma J and Kruk M, Colloid Surface A., 2003, 214, 263; (b) Grebennikov S F and Udal'tsova N N, Colloid J., 2006, 68, 541.

29. (a) Khodaei M M, Khosropour A R and Fattahpour P, Tetrahedron Lett., 2005, 46, 2105;. (b) Mao H, Wan J and Pan Y, Tetrahedron., 2009, 65, 1026-1032. (c) Rao I N, Prabhakaran E N, Das S K and Iqbal J, J Org Chem., 2003, 68, 4079.

30. Bahulayan D, Das S K and Iqbal J, J Org Chem., 2003, 65, 5735-5738.

31. Rafiee E, Tork F and Joshaghani M, Bioorg Med Chem Lett., 2006, 16, 1221-1226. 


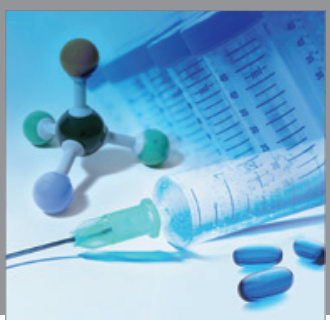

International Journal of

Medicinal Chemistry

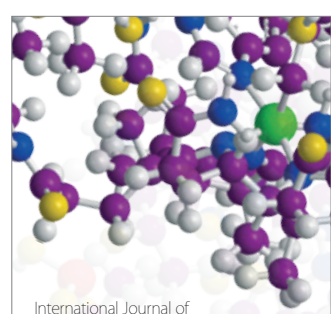

Carbohydrate Chemistry

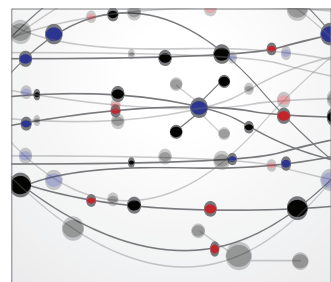

The Scientific World Journal
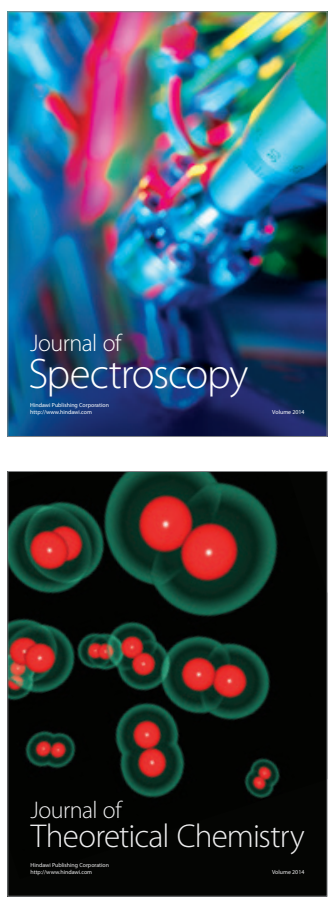
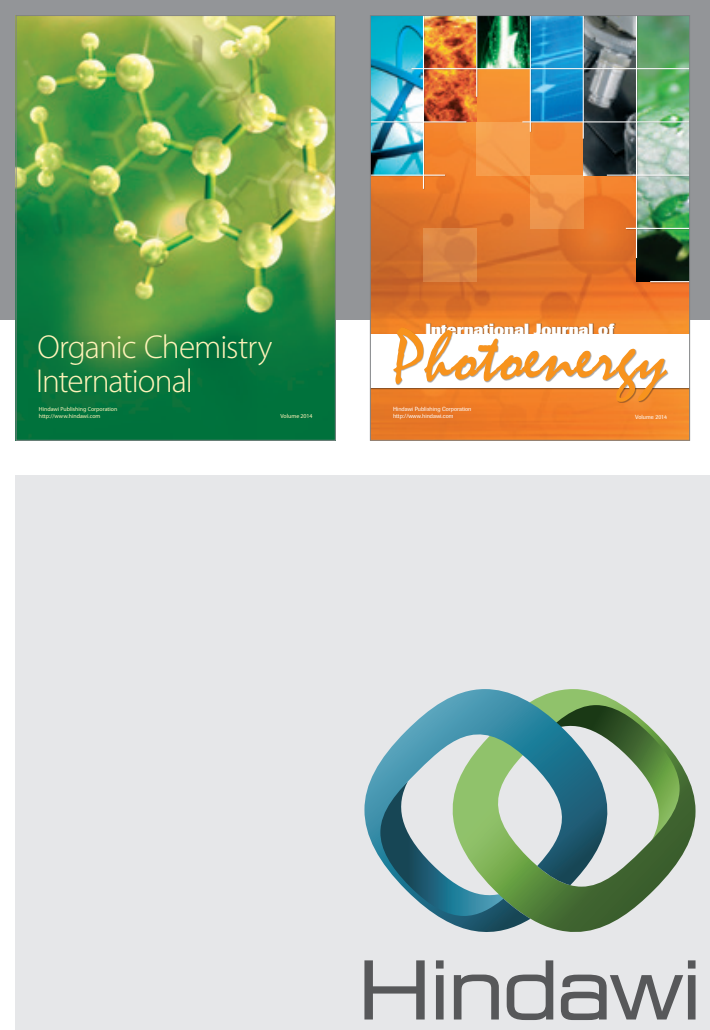

Submit your manuscripts at

http://www.hindawi.com
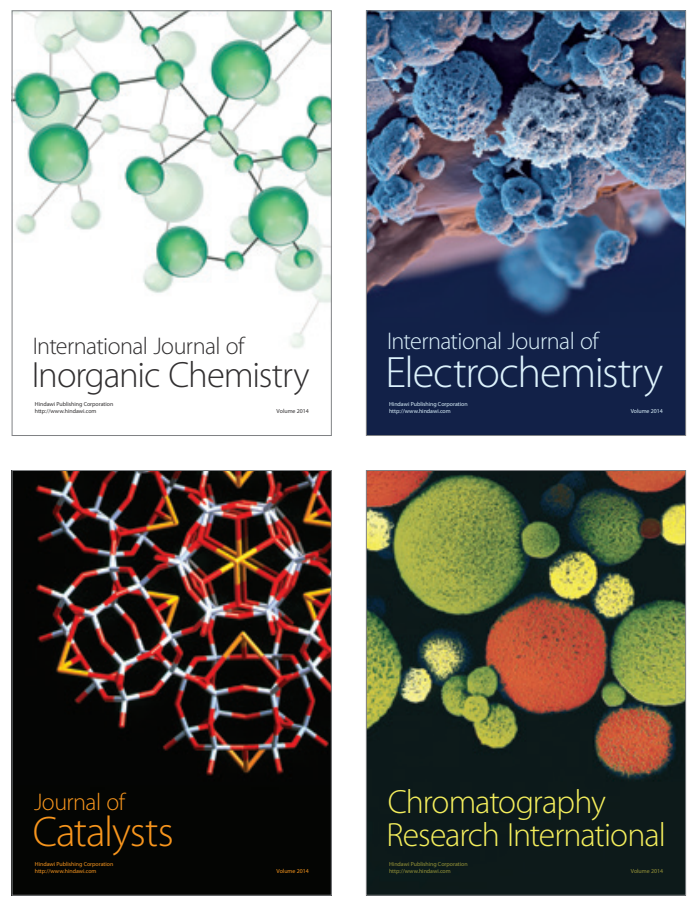
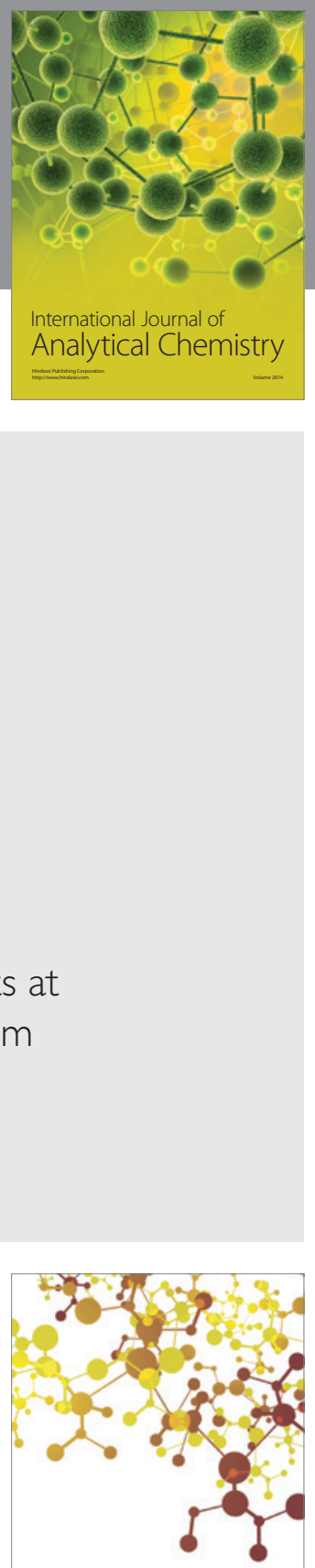

Journal of

Applied Chemistry
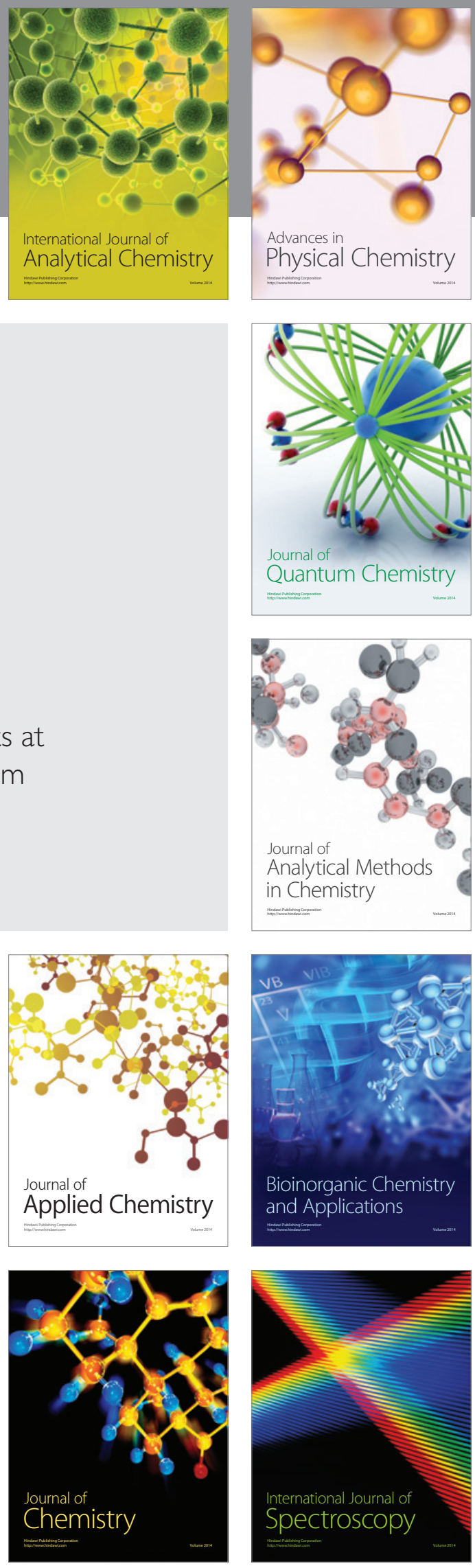